\title{
ANALISIS TINGKAT KECOCOKAN PENGGUNAAN BATU BATA PUTIH SEBAGAI BAHAN DASAR PEMBANGUNAN SELOKAN MENGGUNAKAN KONFIGURASI WENNER
}

\author{
Theresia Purba, Dinda Maulina, Vareyna Tsamrotul Fikriyah, Ahdi Awaludin Sholeh, Regian \\ Erstelle Bowo, Widya Utama* \\ Departemen Teknik Geofisika, Fakultas Teknik Sipil Perencanaan dan Kebumian, \\ Institut Teknologi Sepuluh Nopember \\ *Penulis Korespondensi : widya@geofisika.its.ac.id
}

\begin{abstract}
Abstrak. Konstruksi bangunan seperti gedung, jembatan, selokan dan lainnya memerlukan bahan bangunan yang berkualitas. Umumnya selokan memanfaatkan beton yang sudah ditetapkan sesuai standar. Penelitian ini bertujuan untuk mengetahui tingkat kecocokan penggunaan batu bata putih sebagai bahan substitusi dalam pembuatan selokan yang ditinjau dari potensi resapan air dengan metode geolistrik konfigurasi wenner serta memperhatikan parameter fisis batuan (densitas, porositas, daya serap air, resistivitas, dan kapilaritas). Data porositas, densitas, dan daya serap air digunakan sembilan sampel batu bata putih berbeda yang kemudian diseleksi untuk diperoleh data sesuai standar. Densitas batu bata putih berkisar 600-1800 gr/m³, sedangkan porositasnya berkisar 21-45\%. Rata-rata daya serap air dari sampel yang nilai densitas dan porositasnya sesuai dengan standar adalah $22.93 \%$. Daya serap batu bata putih dianggap kurang baik karena melebihi nilai SNI-10-78 Pasal 6.2.4 (kurang dari 20\%). Pemodelan resistivitas 2D menggunakan software Res2Dinv dilakukan untuk mengetahui potensi rembesan air. Hasil pemodelan menunjukkan rentang nilai resistivitas berkisar antara 1,36-1995 $\Omega \mathrm{m}$ sehingga material penyusun batuan diprediksi berupa pasir, kerikil, dan alluvium. Dari semua sampel kering yang digunakan masih diindikasikan adanya air yang ditandai dengan nilai resistivitas air sebesar $0.5-300 \Omega \mathrm{m}$. Analisis kapilaritas dilakukan pada permukaan dan bagian dalam batuan berdasarkan parameter ketinggian dan waktu rembesan air. Diketahui bahwa waktu yang dibutuhkan air untuk merambat pada seluruh tubuh batuan relatif lama tergantung pada luas penampang dan tinggi maksimum sampel yang digunakan. Sehingga batu bata putih tidak direkomendasikan untuk digunakan sebagai bahan substitusi dalam pembuatan selokan sebab memiliki daya serap air dan daya simpan air yang relatif tinggi.
\end{abstract}

Kata Kunci: bata putih; daya serap; kapilaritas; konfigurasi wenner; resistivitas

\begin{abstract}
Construction buildings like buildings, bridges, gutters and others requires quality building materials. Generally, gutters use concrete which according to standards. This study purpose to determine level suitability using white bricks as substitute material in manufacture gutters in terms water infiltration potential white bricks using wenner configuration geoelectric method and regard rock physics parameters (density, porosity, water absorption, resistivity, and capillarity). Porosity, density, and water absorption data using 9 different samples white bricks then selected to get data according standards. Density of white brick around $600-1800 \mathrm{~kg} / \mathrm{m} 3$ and porosity ranged 21 - 45\%. Calculation of water absorption required density and poristy according standard obtained 22.93\%. Water absorption consider bad because exceeds standard value NI-10-78 Article 6.2.4 (below 20\%). 2D resistivity modeling using Res2Dinv software was used to determine potential water seepage. Modeling results show range resistivity values in all samples ranged 1.36 - $1995 \Omega m$ so rock material is predicted to be sand, gravel, and alluvium. From dry sample that used, water is indicated, showed by water resistivity $0.5-300 \Omega \mathrm{m}$. Capillary analysis carried out on surface and inside the rock based height and time of water seepage parameters. Known time required for water to propagate throughout the rock body relatively long depending on the area and the maximum height of the sample used. So that white stone sample not recommended to be used as a substitute material in making gutters or water channels because has relatively high water absorption and high water retention capacity. Keywords: white brick; absorption; capillary; wenner configuration; resistivity
\end{abstract}

\section{PENDAHULUAN}

Dalam konstruksi bangunan baik rumah, jembatan, jalan, dan sejenisnya tentunya membutuhkan material bangunan dengan kualitas yang baik. Selokan merupakan salah satu jenis bangunan berupa saluran yang berfungsi untuk mengalirkan fluida untuk dibawa ke suatu tempat. Material bangunan yang cocok untuk pembuatan selokan ini tentunya harus memiliki standar yang baik yaitu air tidak mudah rembes pada dinding 
selokan. Dimana rembesan ini dapat menyebabkan kerusakan tanah apabila air limbah domestik mengandung bahan-bahan berbahaya. Rembesan pada batuan dipengaruhi oleh sifat fisis batuan yaitu kemampuannya dalam menyerap dan menyimpan suatu fluida, sebab batuan selalu memiliki pori di dalamnya berupa rongga atau celah kecil yang terbentuk selama proses pembatuan atau litifikasi yang disebut dengan kapilaritas. Sehingga penelitian ini bertujuan untuk mengetahui tingkat kecocokan penggunaan batu bata putih sebagai bahan dasar pembangunan selokan ditinjau dari potensi resapan air pada batu bata putih menggunakan konfigurasi wenner. Parameter yang digunakan dalam penelitian ini adalah densitas, porositas, resistivitas, kapilaritas air, dan daya serap air pada batu bata putih.

Secara umum, densitas batuan adalah perbandingan massa dengan volume total batuan. Densitas merupakan sifat fisis batuan yang menggambarkan kerapatan atau ikatan antar material penyusun batuan (Ridha dan Darminto, 2016). Semakin besar nilai densitas suatu material artinya molekul penyusunnya semakin rapat (Giancoli, 2005). Nilai densitas batuan berkaitan dengan kemampuannya untuk menyerap air sehingga kekuatan bahan akan menurun (Kapasiang dkk., 2017). Menurut Tjokrodimulyo (2007), batu bata putih adalah batu bata dengan nilai densitas $600-1800 \mathrm{~kg} / \mathrm{m}^{3}$ dengan persamaan

$\rho=\frac{W_{n}}{W_{w}-W_{s}}$

dengan:

$\rho \quad:$ Densitas $\left(\mathrm{gr} / \mathrm{cm}^{3}\right)$

$W_{n} \quad$ : Massa awal (gr)

$W_{w} \quad:$ Massa jenuh (gr)

$W_{S} \quad$ : Massa jenuh yang tergantung pada air (gr)

Porositas merupakan perbandingan volume pori terhadap volume total batuan yang dapat dinyatakan dalam rentang $0-100 \%$. Porositas dipengaruhi oleh jenis bahan, ukuran, distribusi pori, sementasi, riwayat diagentik, dan komposisinya (Ridha dan Darminto, 2016). Menurut Rohman (2018), nilai porositas batu bata putih berkisar 21 $45 \%$ dengan persamaan

$\phi=\frac{W_{w}-W_{o}}{W_{w}-W_{s}} x 100 \%$ dengan:

$\phi \quad$ : Porositas (\%)

$W_{o} \quad$ : Massa kering (gr)

Bata adalah material yang mudah menyerap air. Jika bata tersebut berkualitas tinggi daya serap airnya rendah. Berdasarkan SNI-10-78 Pasal 6.2.4, jika bata memiliki daya serap air $<20 \%$ bata tersebut disebut baik (Ardi dkk., 2016; Pramono dkk., 2014). Rembesan air dipengaruhi oleh kuat serapan air (absorpsi) pada batuan sehingga penyerapan air merupakan rasio berat air yang terserap ke dalam pori terhadap berat kering batuan dalam persen. Persentase penyerapan air dirumuskan sebagai berikut:

$W_{a}=\frac{W_{w}-W_{o}}{W_{o}} \times 100 \%$

dengan:

$W_{a} \quad$ : water absorption (\%)

(Hunggurami dkk., 2014)

Menurut Koesoemadinata (1980), kapilaritas merupakan kemampuan zat untuk menarik zat lain ke dalamnya ketika gaya adhesi antara fluida dan zat tersebut lebih besar dari gaya kohesi di dalam fluida. Hal ini yang menyebabkan media berpori dapat menyerap fluida. Tekanan kapiler merupakan kemampuan pori batuan untuk mengisi pori batuan dengan fluida. Tekanan kapiler yang ada dalam batuan berpori berbeda-beda bergantung pada jenis fluidanya.

Metode geolistrik resistivitas memanfaatkan variasi resistivitas yang dapat digunakan untuk mendeteksi kontaminan cair dalam tanah yang sering diasosiasikan sebagai fluida konduktif (Oladapo dkk., 2013; Suhendra, 2006). Arus listrik dimasukkan ke permukaan bumi lalu diukur beda potensialnya (Telford dkk., 1990). Metode geolistrik memanfaatkan hukum ohm, dimana arus yang mengalir (I) sebanding dengan tegangan (V) yang terukur, dan berbanding terbalik terhadap resistansi (R). Hasil pengukuran beda potensial dan arus akan memperoleh nilai tahanan jenis yang dapat digunakan untuk menggambarkan keadaan bawah permukaan (Wardhana dkk., 2017). 
Salah satu metode pengukuran geolistrik untuk mencari nilai resistivitas adalah konfigurasi wenner. Konfigurasi wenner menggunakan susunan jarak antar elektroda adalah sama $\left(r_{1}=r_{4}=a\right)$ dan $\left(r_{2}=r_{3}\right.$ $=2 a$ ). Jarak antara elektroda arus adalah tiga kali jarak elektroda potensial, jarak potensial dengan titik sounding-nya adalah a/2, maka jarak masing elektroda arus dengan titik sounding-nya adalah $3 a / 2$. Target kedalaman yang mampu dicapai pada metode ini adalah a/2. Dalam akuisisi data lapangan susunan elektroda arus dan potensial diletakkan simetri dengan titik sounding. Pada konfigurasi wenner jarak antara elektroda arus dan elektroda potensial adalah sama (Gambar 1).

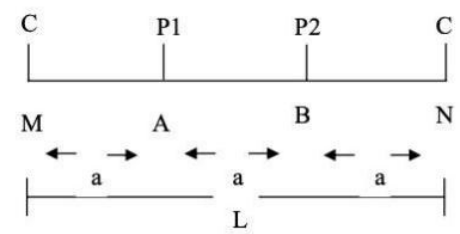

Gambar 1. Elektroda arus dan potensial pada konfigurasi wenner

Berdasarkan Gambar 1, diketahui bahwasanya jarak $A M=N B=a$ dan jarak $A N=M B=2 a$, sehingga diperoleh:

$K=\frac{2 \pi}{\left[\left(\frac{1}{a}-\frac{1}{2 a}\right)\left(\frac{1}{2 a}-\frac{1}{a}\right)\right]}$

$K=2 \pi a$

dengan:

K : Faktor geometri

a : Jarak antar elektroda (m)

(Wijaya, 2015)

Pada medium heterogen dengan spasi elektroda yang bervariasi tentu akan menghasilkan pengukuran nilai resistivitas yang berbeda-beda untuk masing-masing lapisan. yang disebut dengan resistivitas semu. Resistivitas semu dapat diketahui melalui persamaan berikut :

$\rho_{a}=K \frac{\Delta V}{I}$

dengan:

$$
\begin{array}{ll}
\rho_{a} & : \text { Resistivitas semu }(\Omega \mathrm{m}) \\
K & : \text { Faktor geometri } \\
\Delta V & : \text { Beda potensial (volt) } \\
I & : \text { Arus (A) }
\end{array}
$$

(Telford dkk., 1990)
Data resistivitas semu sebagai hasil interpolasi dapat dilakukan pemodelan bawah permukaan menggunakan program Res2Dinv yaitu penampang geolistrik 2 dimensi. Hasil dari penampang tersebut dapat dilakukan analisis pada setiap perlapisan berdasarkan nilai resistivitasnya yang dapat digunakan untuk menentukan jenis litologi lapisan menurut Telford dkk. (1990). Klasifikasi jenis litologi berdasarkan nilai resistivitas dapat dilihat pada Tabel 1.

Tabel 1. Nilai resistivitas sebagai material material bumi (Telford dkk., 1990)

\begin{tabular}{ccc}
\hline No & Material & Resistivitas $(\Omega \mathrm{m})$ \\
\hline 1 & Udara & 0 \\
2 & Pasir & $1-1000$ \\
3 & Lempung & $1-100$ \\
4 & Air tanah & $0.5-300$ \\
5 & Air asin & 0.2 \\
6 & Keririk kering & $600-10.000$ \\
7 & Aluvium & $10-800$ \\
8 & Kerikil & $100-600$ \\
\hline
\end{tabular}

\section{METODOLOGI}

Dalam penelitian ini menggunakan data primer hasil praktikum, dimana dalam mendapatkan parameter fisisnya dilakukan tiga perlakukan berbeda dengan sampel berbeda pula. Penelitian ini menggunakan analisis nilai densitas, porositas (\%), daya serap (\%), resistivitas, dan kapilaritas air pada batu bata putih.

Data yang digunakan dalam analisis nilai densitas, porositas, dan daya serap batu bata putih menggunakan sembilan data sampel batuan berbeda. Selanjutnya dilakukan seleksi data menggunakan crossplot yang dibandingkan dengan rentang nilai densitas, porositas, dan daya serap batu bata putih berdasarkan penelitian terdahulu.

Data yang digunakan dalam analisis resistivitas dan kapilaritas air pada batuan menggunakan empat sampel batu bata putih yang berbeda (sampel A, B, $C$, dan D). Pengukuran resistivitas dilakukan dengan menggunakan konfigurasi wenner dimana, sampel A dan sampel $C$ berukuran $60 \times 19 \mathrm{~cm}$ sedangkan sampel B dan sampel D berukuran $60 \times 7,5 \mathrm{~cm}$ dengan jarak antar elektroda pada sample $A$ dan sampel B sebesar $2,5 \mathrm{~cm}$ sehingga didapatkan 24 
elektroda, sedangkan pada sampel C dan sampel D sebesar $1 \mathrm{~cm}$ sehingga didapatkan 59 elektroda.

Dari hasil pengukuran menggunakan konfigurasi wenner diperoleh data tegangan dan arus pada masing-masing datum untuk setiap sampel batu bata putih. Kemudian data tersebut diolah untuk dilakukan perhitungan resistivitas. Dari data pengukuran dan perhitungan tersebut dapat dibuat pemodelan resistivitas 2D menggunakan software Res2Dinv. Data input yang digunakan yaitu distribusi nilai pa, jarak antar elektroda, jumlah data, serta elevasi setiap elektroda.

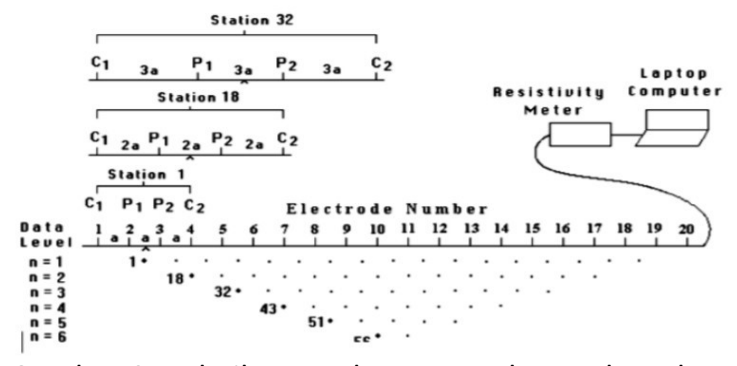

Gambar 2. Teknik pengukuran untuk mendapatkan profil 2D (Loke dan Barker, 1996)

Untuk menganalisis rembesan batu bata putih, dilakukan pula pengambilan data kapilaritas fluida sampel batu bata putih dengan mencelupkan sampel A dan sampel $C$ pada air setinggi $8 \mathrm{~cm}$, pada sampel B setinggi $1 \mathrm{~cm}$, dan pada sampel $D$ setinggi $3 \mathrm{~cm}$. Kemudian dihitung waktu kemampuan air untuk merambat pada batuan baik pada permukaan sampel yang diamati menggunakan mata secara langsung dan juga melalui pengamatan dalam permukaan sampel menggunakan metode Konfigurasi wenner. Dari hasil percobaan didapatkan data berupa waktu kenaikan resapan air dan ketinggian resapan air. Kemudian, dapat dilakukan analisis perbandingan ketinggian terhadap waktu kenaikan air pada masing-masing sampel.

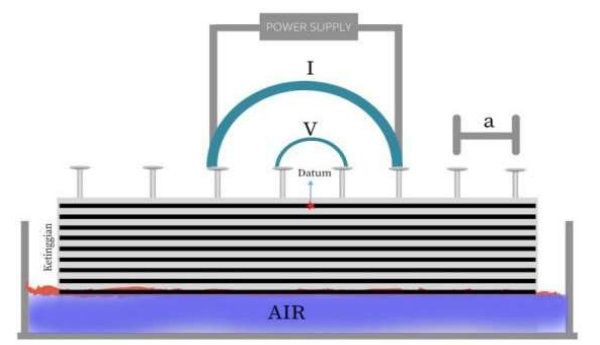

Gambar 3. Desain akuisisi data praktikum resistivitas konfigurasi wenner dan kapilaritas

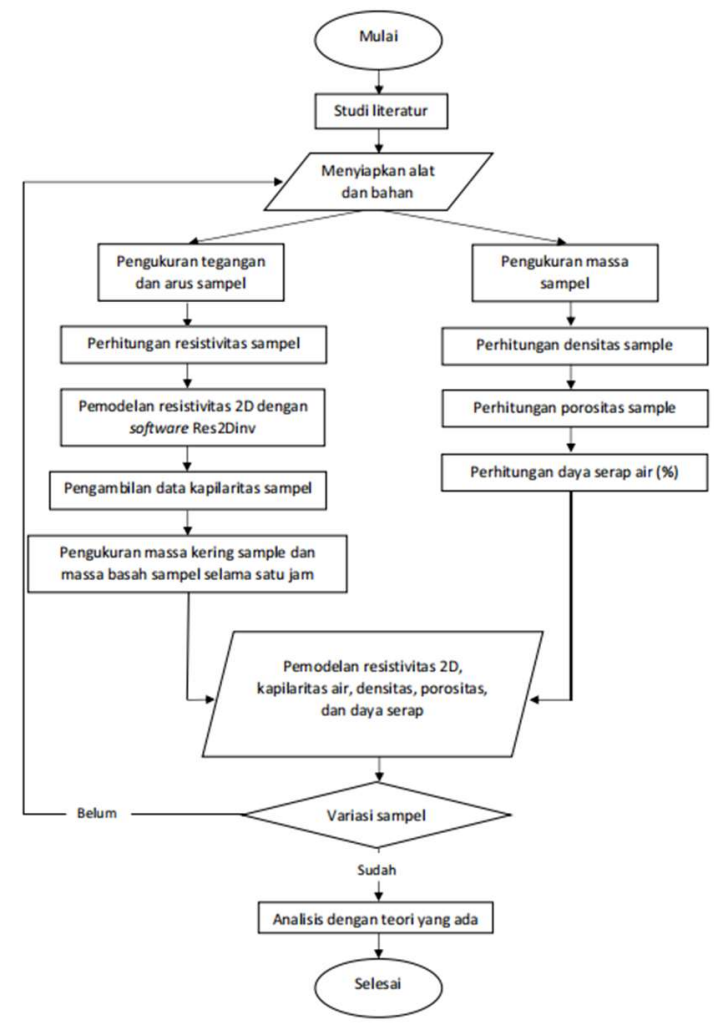

Gambar 4. Diagram Alir Penelitian

\section{HASIL DAN PEMBAHASAN}

Penelitian ini bertujuan untuk mengetahui tingkat kecocokan penggunaan batu bata putih sebagai bahan dasar pembangunan selokan ditinjau dari potensi resapan air pada batu bata putih menggunakan metode geolistrik konfigurasi wenner. Parameter yang digunakan berupa densitas, porositas (\%), daya serap (\%), resistivitas, dan kapilaritas air pada batu bata putih.

Tabel 2 menunjukkan nilai densitas, porositas, dan daya serap air masing-masing sampel. Seleksi data dilakukan cross-plot untuk menentukan nilai densitas dan porositas yang kurang sesuai berdasarkan referensi penelitian terdahulu (Rohman, 2018; Tjokrodimulyo, 2007). Gambar 5 menunjukkan plot grafik dari data Tabel 2. Menurut Tjokrodimulyo (2007), batu bata putih adalah batu bata dengan nilai densitas $600-1800 \mathrm{~kg} / \mathrm{m} 3$, sehingga simbol segitiga hijau menunjukkan data densitas yang kurang sesuai. Menurut Rohman (2018), nilai porositas batu bata putih berkisar 21 $45 \%$, sehingga nilai porositas yang kurang sesuai ditunjukkan oleh simbol kotak kuning, sedangkan 
Tabel 2. Nilai Densitas, Porositas, dan Daya Serap 9 Sampel Batuan Berbeda

\begin{tabular}{ccccccccc}
\hline Sampel & Wn & Wo & Ww & Ws & $\rho$ & \multicolumn{2}{c}{$\begin{array}{c}\text { Daya Serap } \\
(\%)\end{array}$} \\
\hline 1 & 295.5 & 291.5 & 309.3 & 144.8 & 8.63 & 1.80 & 4.81 \\
2 & 178 & 177 & 223 & 92.5 & 35.25 & 1.36 & 25.99 \\
3 & 232.1 & 229.8 & 248.4 & 145 & 17.99 & 2.24 & 8.09 & 18.48 \\
4 & 125 & 110 & 130.33 & 46 & 24.11 & 1.48 & 74.55 \\
5 & 65 & 55 & 96 & 48 & 85.42 & 1.35 & 50.85 \\
6 & 65 & 59 & 89 & 40 & 61.22 & 1.33 & 22.39 \\
7 & 71 & 667 & 82 & 26 & 26.79 & 1.27 & 84.31 \\
8 & 62 & 51 & 94 & 46 & 89.58 & 1.29 & 1.73 & 24.87 \\
9 & 1378 & 1198 & 1496 & 698 & 37.34 & & \\
\hline
\end{tabular}

simbol warna hitam menunjukkan daya serap yang kurang sesuai terhadap nilai densitas dan porositasnya.

Hasil seleksi data porositas, densitas, dan daya serap yang sesuai ditunjukkan oleh sampel $B, D, G$, dan I dengan nilai densitas rentang $1,27-1,73 \mathrm{~g} / \mathrm{cm}^{3}$, sedangkan nilai porositas pada rentang $24,11-37,34$ $\%$. Hasil perhitungan daya serap menggunakan persamaan (1) pada masing-masing sampel B, D, G, dan I sebesar 25,99\%; 18,48\%; 22,39\%; 24,8\% dengan rata-rata daya serap $22,93 \%$. Berdasarkan SNI-10-78 Pasal 6.2.4 batu bata dianggap baik bila memiliki daya serap air kurang dari 20\% (Ardi dkk., 2016; Pramono dkk., 2014). Sehingga sampel yang digunakan dianggap kurang baik karena daya serap lebih besar dari $20 \%$.

Dalam analisis rembesan air pada batuan dapat dilakukan pemodelan resistivitas $2 \mathrm{D}$ berdasarkan data percobaan resistivitas sampel A, B, C, dan D. Berikut hasil pemodelan resistivitas $2 \mathrm{D}$ dengan menggunakan software Res2Dinv.

Hubungan Densitas dengan Porositas dan Daya Serap

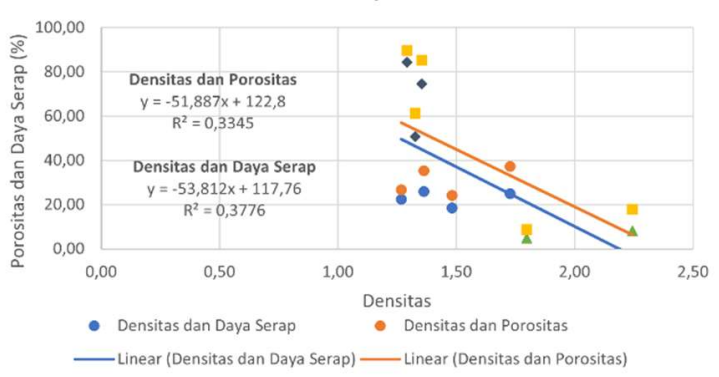

Gambar 5. Hasil cross-plot hubungan densitas dengan porositas dan daya serap air

Pada penelitian ini, sampel batu bata putih yang digunakan merupakan sampel kering. Gambar diatas menunjukkan pemodelan resistivitas $2 \mathrm{D}$ pada sampel $A, B, C$, dan $D$, dimana nilai resistivitas yang diperoleh pada masing-masing sampel batuan relatif bervariasi berkisar 1,36 - $1995 \Omega \mathrm{m}$. Dimana berdasarkan klasifikasi oleh Telford (1990), untuk air tanah memiliki nilai resistivitas sebesar 0,5-300 $\Omega \mathrm{m}$. Sehingga pada gambar 6 dan 9, nilai resistivitas air untuk sampel $A$ dan $D$ terakumulasi pada bagian permukaan batu bata putih di kedalaman sekitar 0,00625 - 0,0463 m dan 0,00250 - 0,0396 m. Sedangkan pada Gambar 7 dan 8, diketahui nilai resistivitas air untuk sampel $B$ dan $C$ terakumulasi pada semua bagian batu bata putih di kedalaman sekitar 0,00625-0,0797 m dan 0,0250-0,788 m.

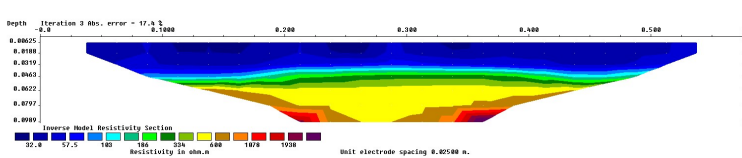

Gambar 6. Model resistivitas 2D sampel A

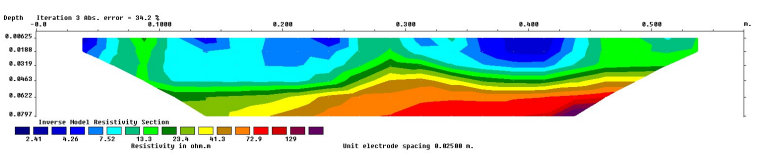

Gambar 7. Model resistivitas 2D sampel B

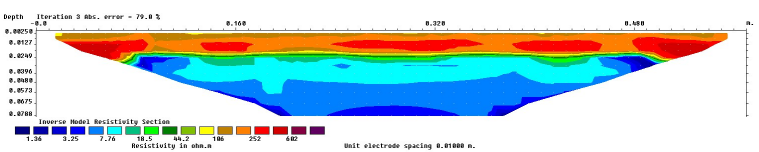

Gambar 8.Model resistivitas 2D sampel C

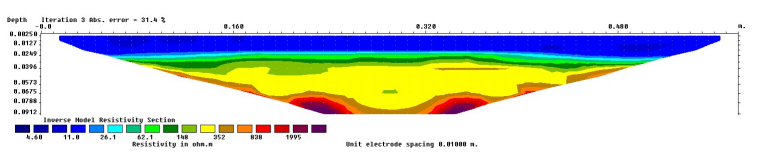

Gambar 9. Model resistivitas 2D sampel D

Hasil pemodelan resistivitas 2D menunjukkan nilai resistivitas berkisar 1,36 - $1995 \Omega \mathrm{m}$ dan sifat fisis dari batu bata putih adalah homogen isotropis. 
Maka dapat diprediksikan bahwasannya batu bata putih tersusun dari beberapa material, yaitu pasir, kerikil, dan alluvium berdasarkan klasifikasi Telford (1990).

Berdasarkan Gambar 7 dan 8 dapat diinterpretasikan daerah terakumulasi air yang menunjukkan bahwa sampel batu bata putih kering yang digunakan diindikasi masih memiliki banyak kandungan air. Sehingga batu bata putih memiliki karakteristik daya simpan air yang tinggi.

Adapun analisis lainnya ditinjau dari lama waktu kapilaritas air pada batu bata putih berdasarkan resapan air pada permukaan dan bagian dalam batu bata putih. Identifikasi kapilaritas air pada bagian permukaan dapat diamati secara langsung, sedangkan identifikasi kapilaritas air pada bagian dalam batuan ditandai dengan perubahan nilai resistivitas yang diukur pada datum tertentu di setiap level menggunakan konfigurasi wenner. Data kapilaritas batu bata putih ditunjukkan oleh Tabel 3, 4, 5, dan 6 .

Tabel 3. Data Kapilaritas Permukaan Batu Bata Putih pada Bidang Ukur $60 \times 7,5 \mathrm{~cm}$

\begin{tabular}{|c|c|c|c|c|}
\hline \multirow{3}{*}{$\begin{array}{l}\text { Bidang } \\
\text { ukur }\end{array}$} & \multicolumn{4}{|c|}{ Kapilaritas Permukaan } \\
\hline & \multicolumn{2}{|c|}{ Sampel A } & \multicolumn{2}{|c|}{ Sampel B } \\
\hline & Waktu (s) & $\begin{array}{c}\text { Ketinggian } \\
(\mathrm{cm})\end{array}$ & Waktu (s) & $\begin{array}{c}\text { Ketinggian } \\
(\mathrm{cm})\end{array}$ \\
\hline \multirow{6}{*}{$\begin{array}{l}\frac{E}{u} \\
\text { ก } \\
\\
\times \\
0\end{array}$} & 14 & 9.625 & 91 & 9.5 \\
\hline & 41 & 10.250 & 199 & 10 \\
\hline & 77 & 10.875 & 337 & 10.5 \\
\hline & 402 & 11.5 & 554 & 11 \\
\hline & 1853 & 12.125 & 1140 & 11.5 \\
\hline & - & - & 4127 & 12 \\
\hline
\end{tabular}

Tabel 4. Tabel 4. Data Kapilaritas Permukaan Batu Bata Putih pada Bidang Ukur $60 \times 19 \mathrm{~cm}$

\begin{tabular}{|c|c|c|c|c|}
\hline \multirow{3}{*}{$\begin{array}{c}\text { Bidang } \\
\text { Ukur } \\
\text { Batuan }\end{array}$} & \multicolumn{4}{|c|}{ Kapilaritas Permukaan } \\
\hline & \multicolumn{2}{|c|}{ Sampel B } & \multicolumn{2}{|c|}{ Sampel D } \\
\hline & $\begin{array}{c}\text { Waktu } \\
\text { (s) }\end{array}$ & $\begin{array}{l}\text { Ketinggian } \\
(\mathrm{cm})\end{array}$ & $\begin{array}{c}\text { Waktu } \\
\text { (s) }\end{array}$ & $\begin{array}{c}\text { Ketinggian } \\
(\mathrm{cm})\end{array}$ \\
\hline \multirow{6}{*}{ 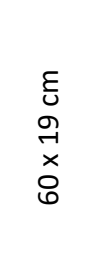 } & 30 & 2.5 & 27 & 3.5 \\
\hline & 507 & 3.75 & 31 & 4 \\
\hline & 967 & 5 & 53 & 4.5 \\
\hline & 17014 & 6.5 & 171 & 5 \\
\hline & - & - & 340 & 5.5 \\
\hline & - & - & 1213 & 6 \\
\hline
\end{tabular}

Tabel 5. Tabel 5. Data Kapilaritas Dalam Permukaan Batu Bata Putih pada Bidang Ukur $60 \times 7,5 \mathrm{~cm}$

\begin{tabular}{|c|c|c|c|c|}
\hline \multirow{3}{*}{$\begin{array}{c}\text { Bidang } \\
\text { Ukur } \\
\text { Batuan }\end{array}$} & \multicolumn{4}{|c|}{ Kapilaritas Bagian Dalam } \\
\hline & \multicolumn{2}{|c|}{ Sampel A } & \multicolumn{2}{|c|}{ Sampel C } \\
\hline & $\begin{array}{l}\text { Waktu } \\
\text { (s) }\end{array}$ & $\begin{array}{l}\text { Ketinggian } \\
(\mathrm{cm})\end{array}$ & $\begin{array}{l}\text { Waktu } \\
\text { (s) }\end{array}$ & $\begin{array}{l}\text { Ketinggian } \\
(\mathrm{cm})\end{array}$ \\
\hline \multirow{12}{*}{ 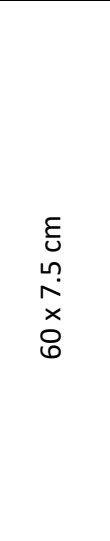 } & 67 & 11.5 & 119 & 9.5 \\
\hline & 453 & 12.75 & 246 & 10 \\
\hline & 794 & 14 & 521 & 10.5 \\
\hline & 1287 & 15.25 & 601 & 11 \\
\hline & 2700 & 16.5 & 755 & 11.5 \\
\hline & - & - & 929 & 12 \\
\hline & - & - & 1113 & 12.5 \\
\hline & - & - & 1383 & 13 \\
\hline & - & - & 1775 & 13.5 \\
\hline & - & - & 2243 & 14 \\
\hline & - & - & 2756 & 14.5 \\
\hline & - & - & 3656 & 15 \\
\hline
\end{tabular}

Tabel 6. Data Kapilaritas Dalam Permukaan Batu Bata Putih pada Bidang Ukur $60 \times 19 \mathrm{~cm}$

\begin{tabular}{|c|c|c|c|c|}
\hline \multirow{3}{*}{$\begin{array}{l}\text { Bidang } \\
\text { Ukur } \\
\text { Batuan }\end{array}$} & \multicolumn{4}{|c|}{ Kapilaritas Bagian Dalam } \\
\hline & \multicolumn{2}{|c|}{ Sampel B } & \multicolumn{2}{|c|}{ Sampel D } \\
\hline & $\begin{array}{l}\text { Waktu } \\
\text { (s) }\end{array}$ & $\begin{array}{l}\text { Ketinggian } \\
(\mathrm{cm})\end{array}$ & $\begin{array}{l}\text { Waktu } \\
\text { (s) }\end{array}$ & $\begin{array}{l}\text { Ketinggian } \\
(\mathrm{cm})\end{array}$ \\
\hline \multirow{9}{*}{ 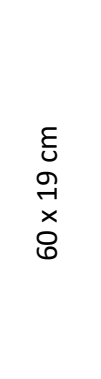 } & 132 & 2.5 & 63 & 3 \\
\hline & 992 & 3.75 & 88 & 3.5 \\
\hline & 11712 & 5 & 123 & 4 \\
\hline & 17809 & 6.25 & 246 & 4.5 \\
\hline & - & - & 470 & 5 \\
\hline & - & - & 785 & 5.5 \\
\hline & - & - & 1128 & 6 \\
\hline & - & - & 1642 & 6.5 \\
\hline & - & - & 2319 & 7 \\
\hline
\end{tabular}

Uji kapilaritas dilakukan pada dua bidang ukur yaitu $60 \mathrm{~cm} \times 19 \mathrm{~cm}$ dan $60 \mathrm{~cm} \times 7,5 \mathrm{~cm}$. Berdasarkan data pada Tabel 3 dan 4 dapat dibuat grafik kapilaritas permukaan batu bata putih (Gambar 10), sedangkan data pada Tabel 5 dan 6 dapat dibuat grafik kapilaritas bagian dalam batu bata putih (Gambar 11).

Berdasarkan Tabel 3 dan 4 diketahui bahwa waktu yang dibutuhkan air untuk merambat pada permukaan batuan berbeda-beda, hal ini dikarenakan pola persebaran pori pada sampel batu bata putih yang digunakan tidak merata. Pada 
sampel A dan $C$ titik maksimum air merambat setinggi 12,125 cm dan $12 \mathrm{~cm}$ dengan waktu $1853 \mathrm{~s}$ dan 4127 s. Pada sampel B dan D titik maksimum air merambat setinggi $6,25 \mathrm{~cm}$ dan $6 \mathrm{~cm}$ dengan waktu $17014 \mathrm{~s}$ dan $1213 \mathrm{~s}$.

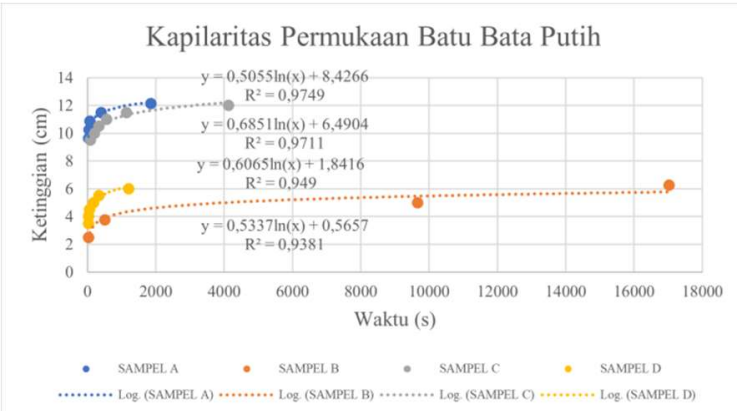

Gambar 10. Grafik perubahan ketinggian air terhadap waktu rambat dalam percobaan kapilaritas pada permukaan batu bata putih

Kapilaritas Bagian Dalam Batu Bata Putih

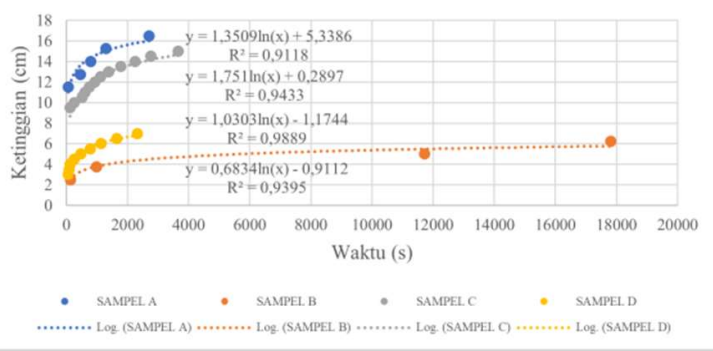

Gambar 11. Grafik perubahan ketinggian air terhadap waktu rambat dalam percobaan kapilaritas pada bagian dalam batu bata putih

Berdasarkan Tabel 5 dan 6 diketahui waktu yang dibutuhkan air untuk merambat pada bagian dalam batu bata putih. Pada sampel $A$ dan $C$ titik maksimum air merambat setinggi $16,5 \mathrm{~cm}$ dan $15 \mathrm{~cm}$ dengan waktu $2700 \mathrm{~s}$ dan $36530 \mathrm{~s}$. Sedangkan pada sampel B dan $D$ titik maksimum air merambat setinggi $6,25 \mathrm{~cm}$ dan $7 \mathrm{~cm}$ dengan waktu $17809 \mathrm{~s}$ dan $2319 \mathrm{~s}$.

Berdasarkan analisis yang telah dilakukan, diketahui bahwa waktu yang dibutuhkan air untuk merambat pada bata putih yang luas penampangnya lebih lebar $(60 \mathrm{~cm} \times 19 \mathrm{~cm})$ dibutuhkan waktu yang relatif lebih lama daripada luas penampang yang lebih kecil $(60 \mathrm{~cm} \times 7,5 \mathrm{~cm})$. Hal ini dapat diasumsikan bahwa kapilaritas berhubungan dengan luas permukaan batuan, ketika batuan direndam dengan air maka air di luas permukaan yang lebih kecil akan mudah merambat dibandingkan dengan permukaan yang lebih lebar sesuai pada Gambar 10 dan 11.
Pada dasarnya kapilaritas memiliki batas maksimum perambatan, sehingga untuk daerah yang jangkauannya lebih jauh dari batas air maka dibutuhkan waktu rambat yang lebih lama dengan ketinggian maksimum tertentu. Ketinggian maksimum terjadi saat gaya tegangan permukaan setara dengan zat cair yang berada pada pipa kapiler (Nugraha, 2020). Dalam hal ini juga berlaku pada batuan dimana tegangan permukaan akan setara dengan zat cair yang meresap pada pori batuan.

Dengan demikian berdasarkan resistivitas batu bata putih berada di rentang 1,36 - $1995 \Omega \mathrm{m}$ yang pada klasifikasi Telford (1990) maka pada batu bata putih terdapat material yang hampir sama dengan beton atau $U$ Ditch (material selokan sesuai standar) yaitu pasir, kerikil, dan ada material yang tidak sama yaitu alluvium. Akan tetapi, saat ditinjau dari daya serap batu bata putih berdasarkan seleksi data dari nilai densitas dan porositasnya hanya 4 sampel yang memenuhi kriteria. Sedangkan rata-rata daya serap dari empat sampel tersebut sekitar 22,93\%. Maka batu bata putih dianggap kurang cocok untuk dijadikan dinding selokan karena memiliki rata - rata daya serap yang masih diatas nilai SNI-10-78 Pasal 6.2.4 yaitu dibawah 20\%. Berdasarkan kapilaritas air, diketahui bahwasannya pada permukaan batu bata putih yaitu $60 \mathrm{~cm} \times 19 \mathrm{~cm}$ dengan tebal 7,5 cm dibutuhkan waktu yang yang dibutuhkan air untuk merambat pada batuan relatif cukup lama. Beton atau $U$ Ditch yang sesuai standar memiliki ketebalan sekitar $8,8 \mathrm{~cm}$, sedangkan lebar dari batu bata putih sendiri itu sekitar $7,5 \mathrm{~cm}$. Sehingga batu bata putih dianggap kurang memenuhi standar karena ketebalannya kurang dari $8,8 \mathrm{~cm}$.

\section{PENUTUP}

\section{Simpulan dan Saran}

Berdasarkan analisis parameter fisis batuan yaitu densitas, porositas, daya serap, resitivitas, dan kapilaritas sampel batu bata putih, penggunaan batu bata putih sebagai bahan substitusi dinding selokan kurang disarankan. Berdasarkan klasifikasi Telford (1990) batu bata putih memiliki maetrial yang hampir sama dengan beton (material selokan sesuai standar). Pada analisis daya serap air, sampel batu 
batu putih tidak memenuhi standar dengan rata-rata 22.93\%. Menurut SNI-10-78 Pasal 6.2.4 jika daya serap air kurang dari $20 \%$, batu tersebut dianggap baik untuk digunakan. Jika ingin tetap menggunakan batu bata putih, disarankan untuk memilih batu bata putih yang tebalnya lebih dari $8,8 \mathrm{~cm}$ untuk mengantisipasi waktu rembesan air menjadi lebih lama.

\section{Ucapan Terima Kasih}

Penulis mengucapkan terima kasih kepada semua pihak yang telah memberikan dukungan dan bantuan yaitu pertama kepada Bapak Widya Utama selaku dosen pengampu Mata Kuliah Fisika Batuan Departemen Teknik Geofisika ITS atas bimbingan dan arahannya selama pembuatan paper ini. Kedua, kepada teman teman dan semua pihak yang telah membantu penulis selama pembuatan paper ini.

\section{DAFTAR PUSTAKA}

Ardi, A.W., Iswadi, I. dan L, M.S. (2016), "Uji Kuat Tekan, Daya Serap Air dan Densitas Material Batu Bata dengan Penambahan Agregat Limbah Botol Kaca", JFT: Jurnal Fisika dan Terapannya, Vol.3, No.1, hal. 6980. http://doi.org/10.24252/jft.v3i0.16834.

Giancoli, D.C. (2005), Physics Principles With Applications, 6 Ed., Pearson, New Jersey.

Hunggurami, E., Bunganaen, W. dan Muskanan, R.Y. (2014), "Studi Eksperimental Kuat Tekan Dan Serapan Air Bata Ringan Cellular Lightweight Concrete Dengan Tanah Putih Sebagai Agregat", Jurnal Teknik Sipil, Vol.3, No.2, hal. 125-136. http://doi.org/10.35508/jts.3.2.125-136.

Kapasiang, T., Bukit, M. dan Tarigan, J. (2017), "Penentuan Morfologi Permukaan Dan Sifat Fisis Serta Sifat Mekanik Batu Bata Asal Tanah Merah Kabupaten Kupang Nusa Tenggara Timur", Jurnal Fisika: Fisika Sains dan Aplikasinya, Vol.2, No.2, hal. 92-100. http://doi.org/10.35508/fisa.v2i2.550.

Koesoemadinata, R.P. (1980), Geologi Minyak dan Gas Bumi, 2, 2 Ed., Institut Teknologi Bandung, Bandung.

Loke, M. dan Barker, R.D. (1996), "Rapid Least-Squares Inversion of Apparent Resistivity Pseudosections Using a Quasi-Newton Method", Geophysical Prospecting, Vol.44, hal. 131-152. http://doi.org/10.1111/j.1365-2478.1996.tb00142.x.

Nugraha, A. (2020), Efek Absorber Antar Muka pada Efisiensi Distilasi Air Energi Surya Jenis Bak, Skripsi,
Sanata Dharma University, Yogyakarta. Diambil dari https://repository.usd.ac.id/37251/.

Oladapo, M., Adeoye-Oladapo, O.O. dan Adebobuyi, F.S. (2013), "Geoelectric Study of Major Landfills in The Lagos Metropolitan Area, Southwestern Nigeria", International Journal of Water Resources and Environmental Engineering, Vol.5, No.7, hal. 387-398. http://doi.org/10.5897/IJWREE12.020.

Pramono, S.A.P., Watiningsih, T. dan Rustendi, I. (2014), "Sampah Sebagai Campuran Bahan Baku Pembuatan Bata", Prosiding Semnas Enterpreneurship, hal. 275294.

Ridha, M. dan Darminto, D. (2016), "Analisis Densitas, Porositas, Dan Struktur Mikro Batu Apung Lombok Dengan Variasi Lokasi Dan Kedalaman", Jurnal Fisika dan Aplikasinya, Vol.12, No.3. http://doi.org/10.12962/j24604682.v12i3.1403.

Rohman, M.N. (2018), Pengaruh Variasi Lama Pengeringan dan Volume Larutan Graphene Oxide Berbahan Dasar Abu Sekam Padi terhadap Kuat Tekan dan Porositas Bata Ringan Jenis Cellular Lightweigt Concrete, Skripsi, Universitas Negeri Yogyakarta, Yogyakarta. Diambil dari https://eprints.uny.ac.id/56630/.

Suhendra (2006), "Pencitraan Konduktivitas Bawah Permukaan Dan Aplikasinya Untuk Identifikasi Penyebaran Limbah Cair Dengan Menggunakan Metode Geolistrik Tahanan Jenis 2D", Jurnal Gradien, Vol.2, No.1, hal. 105-108.

Telford, W.M., Geldart, L.P. dan Sheriff, R.E. (1990), Applied Geophysics, 2 Ed., Cambridge University Press, Cambridge.

http://doi.org/10.1017/CB09781139167932.

Tjokrodimulyo (2007), Teknologi Beton, Biro Penerbit, Yogyakarta.

Wardhana, R.R., Warnana, D.D. dan Widodo, A. (2017), "Identifikasi Intrusi Air Laut Pada Air Tanah Menggunakan Metode Resistivitas 2D Studi Kasus Surabaya Timur", Jurnal Geosaintek, Vol.3, No.1, hal. 17-22.

http://doi.org/10.12962/j25023659.v3i1.2946.

Wijaya, A.S. (2015), "Aplikasi Metode Geolistrik Resistivitas Konfigurasi Wenner Untuk Menentukan Struktur Tanah di Halaman Belakang SCC ITS Surabaya (Halaman 1 s.d. 5)", Jurnal Fisika Indonesia, Vol.19, No.55, hal. 1-5. http://doi.org/10.22146/jfi.24363. 